\title{
The Cytological Studies on Neglected and Underutilized Cucurbit Species with Special Reference to Chayote, an Under-Exploited Species
}

\author{
Sergio G. Olvera-Vazquez ${ }^{1}$, Jorge Cadena-Iñiguez ${ }^{2}$, Syed A. Gilani ${ }^{3}$, Kazuo N. Watanabe ${ }^{{ }^{*}}$ \\ ${ }^{1}$ Tsukuba Plant Innovation Research Center, University of Tsukuba, Tsukuba, Japan \\ ${ }^{2}$ Colegio de Postgraduados, Campus San Luis Potosi, Salinas de Hidalgo, Mexico \\ ${ }^{3}$ Department of Biological Sciences and Chemestry, University of Nizwa, Nizwa, Sultanate of Oman \\ Email: *watanabe.kazuo.fa@u.tsukuba.ac.jp
}

How to cite this paper: Olvera-Vazquez, S.G., Cadena-Iñiguez, J., Gilani, S.A. and Watanabe, K.N. (2019) The Cytological Studies on Neglected and Underutilized Cucurbit Species with Special Reference to Chayote, an Under-Exploited Species. American Journal of Plant Sciences, 10, 1261-1279. https://doi.org/10.4236/ajps.2019.108091

Received: July 2, 2019

Accepted: August 9, 2019

Published: August 12, 2019

Copyright $\odot 2019$ by author(s) and Scientific Research Publishing Inc. This work is licensed under the Creative Commons Attribution International License (CC BY 4.0).

http://creativecommons.org/licenses/by/4.0/

\begin{abstract}
Cucurbitaceae family contains important economic and medical crops, they can be divided into two categories according to the worldwide consumption, use, and production. The Cucurbit Popular Crops $(\mathrm{CuPoC})$ are comprised of cucumber, the Cucurbita group (pumpkin and squash), melon and watermelon. On the other hand, Neglected and Underutilized Cucurbit Species (NU$\mathrm{CuS}$ ) group has been used as food sources, medicinal properties and elements in the elaboration of different types of items. The NUCuS is represented in this review work by bitter gourd, bottle gourd, chayote, ridge gourd, and snake gourd, which are recognized mainly in Asia. The center of origin of the majority of NUCuS was proposed to be in the Old World. In contrast, the origin of chayote or Sechiumedule (Jacq.) Sw. was suggested in the New World, precisely in Mesoamerican region based on linguistic uses and distribution of wild relatives. The environmental factors along with artificial selection, production systems and traditional knowledge have been influenced the evolutionary history of NUCuS, Infraspecific variation of chayote has been reported in Mexico over-described varietal groups. These descriptors were determined based on biochemical and morpho-structural traits; however, cytogenetic analyses are scarce. Specifically, chromosome and nuclear content analyses are important to support botanical groups, analyze artificial selection history, developing breeding and conservation programs. The present review paper discusses agronomic and evolutionary importance based on cytological evidence in NUCuS, mainly in the prominent chayote; with the perspective to prompt breeding, conservation, cytology, structural and functional genomics research for its sustainable utilization.
\end{abstract}




\section{Keywords}

Chayote, Sechiumedule, NUS, Nuclear Content, Chromosome Number, Cucurbit Species

\section{Introduction}

Plant Genetic Resources (PGR) hold potential traits to be used in cultivated plant improvement [1]. Neglected and Underutilized Species (NUS) are included within these resources. These are crops that under different conditions had economic and ethnobotanic value, being an important food resource in agriculture of indigenous people, communities and small towns [2]. Nowadays, it is necessary to use these resources to face current world challenges. The United Nations in coalition with different organisms like the Food and Agricultural Organization of the United Nations developed the Global Plan of Action for the Conservation and Sustainable Utilization of Plant Genetic Resources comprises of 17 goals [3]. The main objectives were ensuring food security, facing undernourishment, famine and poverty based on cultivars that front current environmental stress and marginal areas, encouraging sustainable crop production through input-output balance, and creating new target production areas among others [4] [5]. Through human history approximately 80,000 plant species have been identified as edible, only 7000 taxa are used as food supply [6] [7] [8]. About 30 species have been considered as main world food source crops; from these, ten species cover the $75 \%$ of worldwide calorie requirement: out of them, three species (maize, rice and wheat) provide almost $50 \%$ of the human needs, while 7 species (pearl millet, potato, sorghum, soybean, sugarcane, sugar beet, and sweet potato) sustain the remaining half [9] [10]. The restricted number of crop species has replaced traditional landraces that along to increment in crop production transforms cropping systems, inducing genetic erosion [11] [12]. The utilization of NUS is proposed in order to mitigate genetic erosion, risky agricultural production systems, rural poverty, and undernourishment to achieve food security [13] [14]. Species of the most global economy important plant families contain prominent NUS. Cucurbitaceae family contains important members utilized in food processing industries and fresh vegetable species [15]. Utilization of $\mathrm{Cu}$ curbitaceae family in human history has been documented since over 10,000 to 15,000 year B.P. approximately [16] [17]. According to FAOSTAT [18], the highest production of cucurbits has been reported in Asia in 2013 with an approximate production of $191,431,365$ tons, more than the reported for Africa (11,406,859 ton), Europe (16,231,783 ton), North America (8,731,854 ton), and South America (1,355,075 ton). Vast proportion of this data relies mainly on few crops belonging to three genera: Citrullus Schrad. (watermelon), Cucumis L. (cucumber and melon) and Cucurbita L. (pumpkin and squash). They are the most economic important crops in the family and will be treated as cucurbit 
popular crops $(\mathrm{CuPoC})$ in the present work. E.g.: watermelon is one of cash crops, positioned in the top five fresh fruits consumed, occupying around $7 \%$ of the world area appointed for vegetable production, and reaching an annual world production of 90 million tons [19]. Alternately, Behera [20] reported an annual production of $20,889,375$ ton of gourds, pumpkins, squashes and the neglected or underutilized cucurbit species (NUCuS) discussed in the present review. For example, Cucumis genera that included over 32 species, two of them, gherkin ( $C$. anguria L.) and African horned cucumber ( $C$. metuliferus E. Mey) were utilized as a food and medicinal properties [21] [22]. Nevertheless, present paper focuses on different genera from the most economic important entities, in order to boost up research and utilization of under-exploited Cucurbitaceae member species. The CuPoC and NUCuS members are used for human uses, mainly as food sources, but also for cosmetics, indigenous culture items, jewelry, medicine, storage containers, sponges, ornamental purposes, among others [22] [23]. The $\mathrm{CuPoC}$ is comprised of a limit number of over-utilized species [24] included Citrullus lanatus (Thunb.) Matsum. \& Nakai (watermelon), Cucumis sativus L. (cucumber), Cucumis melo L. (melon), and Cucurbita ssp. L. (pumpkin and squash). On the other hand, the NUCuS includes Beninca sahispida (Tunb.) (ash gourd), Lagenaria siceraria (Molina.) Standley (bottle gourd), Luffa acutangula (L.) Roxb. (ridge sponge), Momordica charantia L. (bitter gourd), Sechiumedule (Jacq.) Sw. (chayote) and Trichosanthes cucumerina L. (snake gourd). The taxonomy category, common name, main utilization, sexual system, life cycle, number of species and cultivars of the proposed NUCuS from the present review are described in Table 1. Even though that Cucurbitaceae is represented by many species, a limited number of members are globally used, among them, NUCuS are crucial to establish new economy sources and mitigate undernourishment based on rational conservation and breeding programs [14]. For example, the chayote has presence over the five continents and manipulated mainly for agriculture purposes for the last twenty years (Table 1) [25]. Even though this species has been commercial, ignored in a vast part of the world, is a staple food some regions; yet is crucial to identify chayote's limitations and propose innovative utilizations, detect gaps in conservation, breeding and crop improvement programs through the analysis of genetic diversity and cytological analysis [26]. For these reasons, the objective of this review paper is described current utilization and importance of NUCuS from six genera, discussing present cytology information available and highlighting the importance of research in this approach of the prominent chayote.

\section{Medical Properties of Domesticated Cucurbit}

The Cucurbitaceae family contains species that are important mainly in the Asian traditional system of medicine. The leaves, buds, fruit, and seeds of NU$\mathrm{CuS}$ members are consumed as treatment of different diseases. Lagena riasiceraria was used in the treatment colitis, diabetes, diuretic, hypertension, 
Table 1. Common name, number of cultivated species, number of species inside of genus, scientific name and more frequent utilization of neglected and underutilized cucurbits (NUCuS).

\begin{tabular}{|c|c|c|c|c|c|c|c|}
\hline Genera & Species & $\begin{array}{l}\text { Common } \\
\text { name }\end{array}$ & Utilization & $\begin{array}{l}\text { Sexual } \\
\text { System }\end{array}$ & $\begin{array}{l}\text { Life } \\
\text { Cycle }\end{array}$ & Species & Cultivated \\
\hline Benincasa Savi. & $\begin{array}{l}\text { hispida (Thunb. ex } \\
\text { Murray) Cogn. }\end{array}$ & Ash gourd & $\begin{array}{l}\text { Food source (flowers, fruit, leaves, seed, } \\
\text { and stem) industrial, medicinal }\end{array}$ & M & An & 1 & 1 \\
\hline Lagenaria Ser. & $\begin{array}{l}\text { Siceraria (Molina) } \\
\text { Stand }\end{array}$ & Bottle gourd & $\begin{array}{l}\text { Food source (fruit, seeds and stem), } \\
\text { industrial (containers, musical } \\
\text { instruments, decoration), medicinal }\end{array}$ & M & An & $5-6$ & 1 \\
\hline \multirow[b]{2}{*}{ Luffa Mill. } & Acutangula (L.) Roxb & $\begin{array}{l}\text { Angled/ridge } \\
\text { gourd }\end{array}$ & Food source (fruit), medicinal & $\mathrm{M}, \mathrm{D}$ & An & \multirow[b]{2}{*}{$5-9$} & \multirow[b]{2}{*}{2} \\
\hline & $\begin{array}{l}\text { Cylindrica (L.) M. } \\
\text { Roem }\end{array}$ & Sponge gourd & $\begin{array}{l}\text { Food source (fruit and leaves), industrial } \\
\text { (filters, sponge) medicinal }\end{array}$ & M & An & & \\
\hline Momordica L. & Charantia L & Bitter gourd & $\begin{array}{l}\text { Food source (flowers, fruit, leaves, and } \\
\text { young shoots), industrial, medicinal, } \\
\text { ornamental }\end{array}$ & M & An & $40-150$ & $\sim 6$ \\
\hline \multirow{2}{*}{ Trichosanthes L. } & $\begin{array}{c}\text { Anguinal Cucumerina } \\
\text { L. }\end{array}$ & Snake gourd & $\begin{array}{l}\text { Food source (fruit, leaves, roots, seeds } \\
\text { and young shoots), medicinal }\end{array}$ & M & An & \multirow{2}{*}{$91-100$} & \multirow{2}{*}{$\sim 15$} \\
\hline & Dioica Roxb. & Pointed gourd & $\begin{array}{l}\text { Food source (fruit, leaves and young } \\
\text { shoots) }\end{array}$ & $\mathrm{D}$ & An & & \\
\hline $\begin{array}{l}\text { Sechium P. } \\
\text { Brownie }\end{array}$ & Edule (Jaqc.) Sw & Chayote & $\begin{array}{l}\text { Food source (fruit, leaves, root, stem } \\
\text { and young shoots), medicinal }\end{array}$ & M & $\mathrm{P}$ & $11-15$ & 2 \\
\hline
\end{tabular}

Acronym description: $\mathrm{M}=$ monoecious, $\mathrm{D}=$ dioecious, $\mathrm{A}=$ andromonoecious, $\mathrm{H}=$ hermaphroditic, $\mathrm{G}=$ gynoecious, $\mathrm{An}=$ annual, $\mathrm{P}=$ perennial [32] [33] [39] [57] [79] [112] [113] [114] [115].

among other [27] [28]. Luffa acutangula and L. cylindrical analgesic, antioxidant, antimicrobial, hypoglycemic activities were reported [19] [29] [30] [31]. Among the NUCuS, Momordica charantia has been more analyzed for its pharmacological compounds because of its abortifacient, antidiabetic, anthelmintic, contraceptive, laxative effects [32] [33]. Alternatively, Trichosan thesdioica and T. cucumerina represent the most analyzed because of its antidiabetic, cardiotonic, diuretic, antiulcer, gastro protective activity [34] [35] [36]. Recently, Sechiumedule has been analyzed for its antimicrobial, anti-inflammatory, cardiotonic, cytotoxic and antitumor action [37] [38] [39] [40] [41]. NUCuS contain important pharmacological compounds that would be a key to face important diseases. Hence, phytochemical studies on NUCuS group, with the aim to identify compounds and their functions are essential.

\section{Taxonomy of Domesticated Cucurbit}

The Cucurbitaceae family contains between 96 to 118 genera and 825 to 1000 species [42] [43] [44]. The main morphological characteristics that represents most of the cucurbits are: hairy climbers' habit, long root system, branched stem, simple 3 - 5 lobed leaves, palmate form being most common, tendrils (simple, bifid or absent), unisexual flowers (yellow and whitish), inferior ovary with parental placentation, high number of large seeds, and the cucurbitacin presence [44] [45]. Related with the sexual system dioecy was proposed to be the ancestral 
condition of this group, an example of this situation was described on Bryona genus has been analyzed [46]. NUCuS from present work has different number of domesticated species (Table 1). Benincasa Savi. genus is represented by only one domesticated B. hispida (ash gourd) [47]. Lagenaria Ser. is represented by five wild species and the cultivated L. Siceraria or bottled gourd [48]. Luffa Mill. genus is composed of approximately five to nine species, being ridge gourd and sponge gourd the domesticated [49] [50]. Momordica L. is a difficult taxonomic group which widespread common names delayed the exact species identification [51] [52]. Around 40 to 150 species have been described, seven of them are the most analyzed: M. balsamina L., M. cochinchinensis (Lour.) Spreng., M. charantia L., M. cymbalaria Fnzl., M. dioica Roxb., M. foetida Schumach., and $M$. sahyadrica Joseph John and Antony [20] [53]. Among these six members $M$. charantia has been widely cultivated, two botanical varieties were recognized: the wild type M. charantia var. muricata (syn. var. abbreviate) and domesticated var. charantia [52]. The genus Sechium P. Brownie has over eleven species, from which $S$. edule and $S$. tacaco (Pittier) C. Jeffrey are the cultivated form [26] [54] [55]. Finally, Trichosanthes genus is one of the largest inside Cucurbitaceae family around 91 species have been described, being $T$. acuminate and T. cucumerina the most utilized [35].

\section{Proposed Origin of Neglected and Underutilized Cucurbit Species}

Cucurbits have tropical and subtropical distribution through the Old and New World [56]. Phylogenetic analysis proposed Asia as the center of origin of this group [57]. Early studies of the cucurbits subdivided them into two subfamilies, Zanonoideae and Cucurbitoideae, the last contained most of the human-interest species [58]. Different studies have been made to elucidate the phylogenetic relationship of cucurbits, but the absence of key species hampered the results [59]. Genomic, chloroplast and mitochondrial loci analysis, allowed to recognize order Cucurbitales (including the Cucurbitaceae family) asmonophyletic, result complemented by their morphology and sexual system [60]. Most of CuPoC and NUCuS members have either African or Asian origin (Figure 1) [58]. The annual and monoecious B. hispidaor ash gourd was proposed to have Indo-Chinese origin and domestication center, but it has not been supported by archeological records [22] [61] [62]; however, some Japanese and Javanese origins are also suggested [23]. Bottle gourd or L. sicerariais distributed in the tropic and subtropic regions; Africa is considered the center of origin of this species, being supported by the presence of five wild congeners and archeological remains [23] [63] [64] [65] [66]. Additionally, archeological records suggested that the bottle gourd arrived in America around 7000 - 10,000 years ago, migration through sea has been analyzed as an explanation of its wide distribution, this information identifies as one of the fist domesticated crops in the human history [25] [28] [67] [68]. The worldwide presence and high morphological variation among the Luffa cultivars hindered the center of origin and domestication 


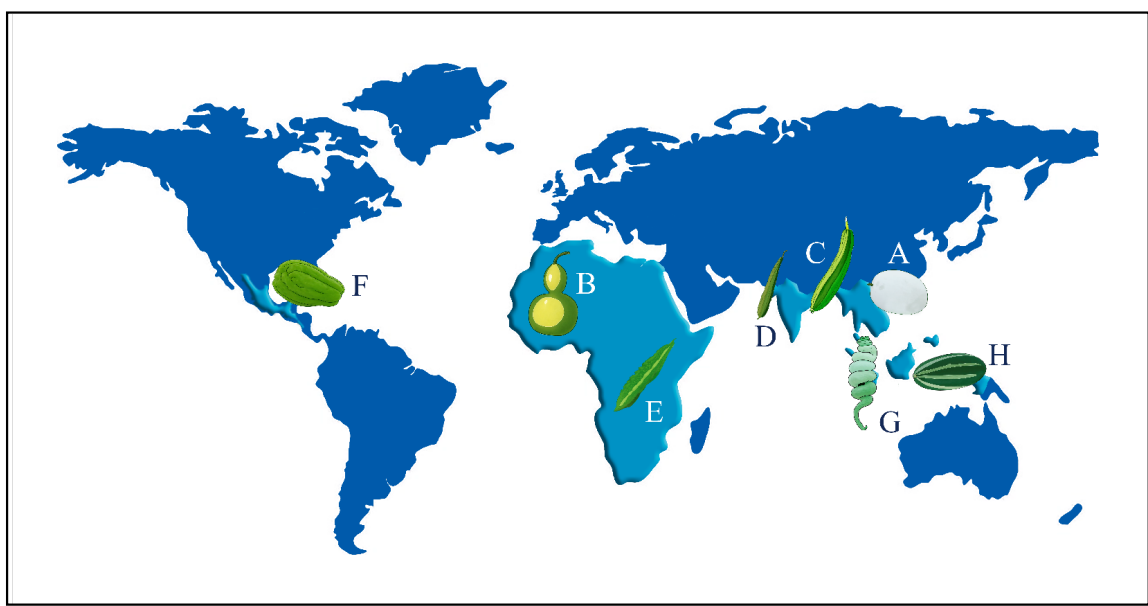

Figure 1. Proposed center of origin of NUCuS. (A) Benincasa hispida (ash gourd) Indo/China region [22] [61] [62] [71]; (B) Lagena riasiceraria (bottle gourd) Africa [22], [48] [49]; (C) Luffa acutangula (sponge gourd) India [22] [49] [56] [69]; (D) Luffa cylindrica (ridge gourd) India [22] [49] [56] [69]; (E) Momordica charantia (bitter gourd) Tropical Africa [72]; (F) Sechium edule (chayote) Mesoamerican region [22] [55] [68] [101] [102]; (G) Trichosan thescumerina (snake gourd) South East Asia [77] [78] [79], and (H) Trichosanthes dioica (pointed gourd) South East Asia [77] [78] [79].

of these species, but the presence of their wild relatives suggested India as the region of these events [22] [49] [56] [69]. Bitter gourd or M. charantia is an Indigenous-Old-World species present currently in all over the subtropics and tropic [70]. Its origin has been widely analyzed. Primarily, the identification of the domesticated and putative wild bitter gourd progenitors was described in the tropical Africa, Asia, and Indian flora postulating this crop as native to the tropic of India or Southeast Asia [61] [71]. Recent phylogenetic analysis suggests that this crop arose in tropical Africa and Asian members appeared from a dispersal event about 19 million years ago [72]. Easter India was considered a primary center of diversity of bitter gourd, based on the presence of its wild form $M$. charantia var. muricata in this area, literature studies, and molecular analysis [73] [74] [75] [76]. The domestication center is not clear due to lack of reliable archeological records, still, China, Eastern India and South-Western India were proposed [22] [71] [73]. The Trichosanthes cultivated species' center of origin and diversification was suggested to be Southeast Asia, and their distribution has been documented from tropical and subtropical Asia: Australia, Fiji, Japan, and New Guinea [77] [78] [79]. Finally, Chayote or S. edule is the only species which center of origin is proposed to be in the New World. More detailed, the center of origin, diversification and domestication of chayote has been proposed to be Mesoamerican [55], based on findings described below.

\section{Chromosome Number Situation of Domesticated Cucurbits}

Cucurbitaceae primitive base number is highly discussed, $\mathrm{n}=12$ is suggested based on its high frequency, followed by $n=7$ and 11, as well as 3 and 5 are 
proposed as primary basic number, while 6 and 10 as secondary [22] [23] [45] [80] [81]. According to several studies autoploidy, alloploidy, aneuploidy, and secondary polyploidy events were presented in the cucurbits' speciation history [42] [45] [81] [82]. Vast number of papers have discussed the NUCuS' chromosomal number, determining a constant value for most species with some exceptions (Table 2). Reports in diploid $\mathrm{CuPoC}$ and NUCuS have postulated $\mathrm{n}=11$ and $2 \mathrm{n}=22$ how the most frequent value followed by $\mathrm{n}=12$ and $13,2 \mathrm{n}=24$ and 26 while the less occurrence were $n=7,14$ and 20,2n =14, 28 and 40 (Table 2). The minor chromosome number described was $\mathrm{n}=7$ in the CuPoC cucumber (C. sativus). Number 11 was reported in high frequency in NUCuS bottle gourd (L. siceraria), bitter gourd (M. charantia), snake gourd (T. cucumerina), and pointed gourd ( $T$. dioica), as well in the $\mathrm{CuPoC}$ watermelon ( $C$. lanatus).The value of $\mathrm{n}=12$ was discussed in ash gourd (B. hispida) and melon (C. melo); while $\mathrm{n}=13$ was debated in species of ridge gourd ( $L$. acutangula) and sponge gourd ( L. cylindrica). Higher number of chromosome number was $\mathrm{n}=20$ identified in different species of Cucurbita spp. (Table 2). Finally, several values have been discussing for chayote ( $S$. edule), $\mathrm{n}=11,12,13$ and 14, proposing a new cytological analysis to elucidate these differences.

\section{Nuclear Content of Domesticated Cucurbits}

Contrary to chromosomal number, nuclear content studies in $\mathrm{CuPoC}$ and NU$\mathrm{CuS}$ are limited (Table 3 ). Nowadays, early cucurbit nuclear content analyses continue being fundamental toper form and understand different methodologies, Ingle et al. [83], Arumuganathan and Earle [84], and Bennett et al. [85]. E. $g$. these values are base for genome size calculation that are available in The Herbarium Catalogue, Royal Botanical Garden, Kewdatabase [85] and reported in some papers, those values are described in Table 3. Even though that $\mathrm{CuPoC}$ has been intensively analyzed due to its higher economic importance, lack of nuclear content research has been proposed, in order to encourage conservation and sustainable utilization of the presented cucurbits crops it is imperative to contrast and confirm the results with up-to-date methodologies complementing and contrasting current information. Table 3 highlights the estimation of nuclear content of the different domesticated cucurbits, allowing the recognition of contrasting values owing to the diverse of material and methodology utilized, following described. First discussions about nuclear content were mainly focused in $\mathrm{CuPoC}$ [83]-[87]. Only the NUCuS bitter gourd, bottle gourd and sponge gourd were analyzed for Ingle et al. [83]. Notwithstanding, bottle gourd and sponge gourd dissimilar values were identified in subsequent analysis [47] [88]. The nuclear content of cultivated pointed gourd was initially studied by Chattopadhyay and Sharma [89], opposite values were obtained in female and male pointed gourd population in a research by Bhowmik and Jha [47]. The biological significance of nuclear content and genome size variation among families, genera, species and cultivars is still not clear, this disparity is independent of 
Table 2. Summary of cucurbit popular crops $(\mathrm{CuPoC})$ and neglected and underutilized cucurbit species (NuCuS) Cucurbits Crops chromosomal number reports.

\begin{tabular}{|c|c|c|c|}
\hline Species & $\mathbf{n}$ & $2 n$ & Source \\
\hline \multicolumn{4}{|c|}{ NUCuS } \\
\hline B. hispida & 12 & 24 & {$[20][22][45][47][62][71][81]$.} \\
\hline L. siceraria & 11 & 22 & [20] [22] [45] [68] [81] [109]. \\
\hline L. acutangula. & 13 & 26 & {$[20][45][81][109]$.} \\
\hline L. cylindrica & 13 & 26 & [20] [22] [45] [37] [81] [109]. \\
\hline M. charantia & 11 & 22 & [20] [22] [45] [52] [53] [80] [81] [109]. \\
\hline T. cucumerina & 11 & 22 & [20] [22] [45] [47] [79] [115]. \\
\hline T. dioica & 11 & 22 & [20] [22] [45] [47] [79] [81] [109] [115]. \\
\hline S. edule & $11,12,13,14$ & $22,24,26,28$ & [20] [22] [26] [37] [54] [56] [68] [81] [109] [116]. \\
\hline \multicolumn{4}{|c|}{ CuPoC } \\
\hline C. lanatus & 11 & 22 & [22] [24] [45] [68] [81] [97] [109]. \\
\hline C. melo & 12 & 24 & [22] [24] [45] [68] [81] [97] [109]. \\
\hline C. sativus & 7 & 14 & [22] [24] [45] [68] [81] [97] [109]. \\
\hline Cucurbita spp. & 20 & 40 & [22] [45] [68] [81] [97] [109] [117]. \\
\hline
\end{tabular}

Table 3. Summary of cucurbit popular crops $(\mathrm{CuPoC})$ and neglected and underutilized cucurbit species (NUCuS) nuclear content reports.

\begin{tabular}{cccc}
\hline Species & $\begin{array}{c}\text { Nuclear content } \\
\text { 2C/pg }\end{array}$ & $\begin{array}{c}\text { Genome size } \\
\text { 2C/Mbp } \\
\text { NUCuS Crops }\end{array}$ & Source \\
\hline B. hispida & $1.97,1.98$ & 1926 & {$[47]$.} \\
L. siceraria & $0.73,1.4$ & 688,1369 & {$[83][85][88]$.} \\
L. cylindrica & $1.70,1.56,3.0$ & 1663 & {$[47][83][85]$.} \\
M. charantia & 4.1 & 4010 & {$[83]$.} \\
T. dioica & $2.27,2.28,2.30,5.65$ & 5526 & [47] [85] [89]. \\
\hline & & CuPoC & [84] [85]. \\
\hline C. lanatus & 0.90 & 880 & [83] [84] [87] [118]. \\
C. sativus & $0.76-2.1$ & 1760 & [83] [85] [86] [87] [119] [120]. [118]. \\
C. melo & $1.9-2.48$ & 1858 & \\
Cucurbita & $0.74-2.6$ & $671-1076$ & \\
spp. & & &
\end{tabular}

the complexity of organism, the C-value paradox [90] [91] [92]. However, diverse studies performed correlating between genome size with cell cycle, life cycle, phenotypic traits (subcellular and organismal level), plant development phases, phenology and ecology interactions [92] [93] [94] [95] [96]. Nowadays, the genome size reported for popular cucurbits has been identified as small compared with important crops like corn (5330 Mbp), onion (32,763 Mbp), 
wheat (33,888 Mbp), among others [97] [98]. The present discussion remarked the scarce number of NUCuS nuclear content research reports, e.g. bitter gourd information is limited, and it was not possible to find meither chayote nor ridge gourd estimations reports. Moreover, the majority of reports belong to $\mathrm{CuPoC}$, reflecting their economic importance. NUCuS is comprised of prominent crops to mitigate with current problems and has potential to become a staple food for low- and middle-income country (LMIC). This situation was discussed in the following section through chayote.

\section{Sechiumedule a Prominent NuCuS}

The genus Sechium P. Brownie has been grouped in the Sycioeae Tribe Schrad. along with the NUCuS Luffa Miller and Trichosanthes L. [99]. Sechium has at least eleven species, from which the chayote and $S$. tacaco (Pittier) C. Jeffrey, are the cultivated form (Table 1 ). The reported wild types were $S$. chinantlense Lira \& F. Chiang, S. compositum (Donn. Sm.) C. Jeffrey, S. hintonii (Paul G. Wilson) C. Jeffrey, S. talamacense (Wunderlin) C. Jeffrey, S. mexicanum Lira \& M. Nee, S. panamense (Wunderlin) Lira \& F. Chiang, S. pittieri (Cogn.) C. Jeffrey, $S$. venosum (L.D. Gómez) Lira \& F. Chiang and $S$. vilosum (Wunderlin) C. Jeffrey [26] [54] [55] [99]. Intraspecific morphological variation has been reported in chayote highly perceptible in fruit anatomy, color, form, flavor and size [84] [86] (Table 4). The center of origin, diversification and domestication of chayote has been proposed to be Mesoamerican [55]. Due to its fleshy fruit there is a lack of archaeological records, pollen grains and plant structures [26]; Yet, historical and linguistic records, in addition of the presence of its wild relatives pointed Mexico as origin site [22] [68] [100] [101] [102]. Furthermore, the highest level of chayote diversity was identified in Mexico, particularly in Chiapas, Oaxaca and Veracruz, maximum intraspecific variation were identified in the central area of Veracruz [100] [103]. In order to classify this variation, a taxonomic arrangement was proposed; morphology and chromosomal number in subspecies S. edule ssp. edule and S. edule spp. Silvestrys [99], nonetheless this did not include cultivars and infraspecific hybrids [104]. Nowadays, ten varietal descriptors were created on morpho-structural, biochemical, physiological and genetic diversity of chayote accessions from the Sechiumedule National Germplasm Bank (BANGESe)-Autonomously University of Chapingo ( $\mathrm{UaCh}$ ) [105]. Chayote production has raised, but it has been focused on the smooth green (virenslevis) varietal group, parallel situation with other cucurbit species [106]. Nowadays, it is imperative to promote chayote varietal groups to avoid the overexploitation of one group and marginalizing others, moreover, the wild type populations are decreasing due to cultivar production practices affecting the surrounding wild groups, e.g. avoid crossed pollination and they are eradicated to establish organic coffee plantations [104]. The improvement of different varieties that replaced old landraces produced genetic erosion, increased the incidence of pests and diseases due to the lack of genetic diversity within the cucurbit gene pool and abiotic stress [107] [108]. The genetic erosion of chayote is 
Table 4. Description of fruit characteristics of ten varietal groups of chayote.

\begin{tabular}{|c|c|c|c|c|c|c|c|}
\hline Variety & Fruit morphology & Peduncle & Mesocarp & Fruit Color & Shape & Size & Flavor \\
\hline albusminor & $\begin{array}{l}\text { Glabrous, absence of } \\
\text { furrows }\end{array}$ & $\begin{array}{l}\text { Slightly pubescence, } \\
\text { light green }\end{array}$ & White & $\begin{array}{l}\text { White-yellow } \\
\text { (Pantone 1205c) }\end{array}$ & Piriform & S & Neutro \\
\hline albus levis & $\begin{array}{l}\text { Glabrous, shallow } \\
\text { furrows }\end{array}$ & $\begin{array}{l}\text { Light green with yellow } \\
\text { striae and slightly } \\
\text { pubescence }\end{array}$ & White & $\begin{array}{l}\text { White-yellow } \\
\text { (Pantone 1205c) }\end{array}$ & Piriform & M & Sweet \\
\hline albusdulcis & Five furrows & $\begin{array}{l}\text { Glabrous light green } \\
\text { with yellow striae }\end{array}$ & White & $\begin{array}{l}\text { White-yellow } \\
\text { (Pantone 1205c) }\end{array}$ & Piriform-round & M & Sweet \\
\hline nigrum conus & Absence of furrows & $\begin{array}{l}\text { Slightly pubescence, } \\
\text { dark green }\end{array}$ & Dark green & $\begin{array}{c}\text { Green } \\
\text { (Pantone 371c and 574c) }\end{array}$ & Conic & M & Sweet \\
\hline nigrum levis & Absence of furrows & Pubescent, dark green & Light green & $\begin{array}{c}\text { Green } \\
\text { (Pantone } 575 c \text { and 576c) }\end{array}$ & Piriform & M & Neutro \\
\hline nigrum maxima & Five slightly furrows & Slightly pubescence & Light green & $\begin{array}{c}\text { Green } \\
\text { Pantone } 373 c \text { and } 7492 c \text { ) }\end{array}$ & Piriform-elongate & B & Neutro \\
\hline nigrum minor & Absence of furrows & $\begin{array}{l}\text { Light green slightly } \\
\text { pubescence }\end{array}$ & Dark green & $\begin{array}{c}\text { Dark green } \\
\text { (Pantone } 374 c \text { and 586c) }\end{array}$ & Round-piriform & M & Neutro \\
\hline nigrum spinosum & Five slightly furrows & Slightly pubescence & Green & $\begin{array}{c}\text { Green } \\
\text { (Pantone 350c and 1205c) }\end{array}$ & Piriform & $\mathrm{M} / \mathrm{B}$ & Neutro \\
\hline nigrum xalapensis & Five furrows & Slightly pubescence & Dark & $\begin{array}{c}\text { Dark green } \\
\text { (Pantone } 575 c \text { and } 5065 c)\end{array}$ & Piriform-elongate & B & Neutro \\
\hline virens levis & Five shallow furrows & $\begin{array}{l}\text { Light green low } \\
\text { pubescence }\end{array}$ & Light green & $\begin{array}{c}\text { Light green } \\
\text { (Pantone 373c) }\end{array}$ & Piriform-elongate & B & Neutro \\
\hline
\end{tabular}

Acronym description: $\mathrm{B}=$ big size $(10.5-15 \mathrm{~cm}), \mathrm{M}=$ medium size $(5.7-8.2 \mathrm{~cm}), \mathrm{S}=(<8.2 \mathrm{~cm}),[24]$ [89] [90].

boosted through the inbreeding and usage of cloned plants in orchids increasing the incidence of viruses and fungal plants infected [101]. The chayote holds high nutritional value with high antioxidant activity, rich in important amino acids (particularly: arginine, aspartic acid, leucine, proline among others), recently it has been pharmacologically analyzed for antimicrobial, anti-inflammatory, cardiotonic, cytotoxic and antitumor action [37]-[41]. In order to take advantage of nutritional and pharmacological properties cytogenetic analyses are proposed. There are a plenty of reports about the Chayote chromosomal number, yet the nuclear content and genome size information is restricted. Initially, research focused on chromosomal description had conflicting results. Singh [109] made a description of the cytogenetics and evolution in the Cucurbitaceae family, describing a karyotypic analysis on 22 large somatic chromosomes in chayote, discussing that three pairs have a secondary constriction and the remaining pairs sub-median constrictions. The different reports identified a diploid state in chayote, but a wide range of chromosomal number. The chromosomal number reported are $2 \mathrm{n}=22,2 \mathrm{n}=24,2 \mathrm{n}=26$, and $2 \mathrm{n}=28$ (Table 2). These variations in chayote would be result of isolation mechanism, aneuploid events, structural rearrangements (fusion or unequal translocation, non-disjunctions of chromosomes, among others) that provided adaptative genes [109] [110]. Different reports found an invariably small chromosome, dying problems, and clustering chromosomes because of secondary metabolites contain [37] [111]. Alternately to the wide chromosome number information available, the nuclear content and 
genome size of cucurbits are scarce, in the case of chayote null.

\section{Conclusion}

Cucurbitaceae family consists of many species, however, human uses rely basically on four of $\mathrm{CuPoC}$, increasing the agriculture vulnerability. NUCuS was postulated as crucial to face poverty, undernourishment and the protection of cucurbit genetic resources. Present review was mainly focused on the need to develop research and encourage utilization of $S$. edule or chayote. Chayote is a prominent Mesoamerican NUCuS resource, that contains high nutritional value and medicinal properties that could be used for food security purposes. Even though chayote has different varietal groups, the commercial and economical value has been focused only on virenslevis or smooth green. Infraspecific chayote variation research is fundamental for rational exploitation and new economic source establishment through ex situ and in situ conservation and breeding programs based on cytological information. However, limited cytogenetic information was identified through the present discussion, this information is a key to analyze the effect of artificial selection in the chayote varietal groups' genome. Chayote is a first insight for the NUCuS utilization based on rational and responsible agricultural management as well as to establish diplomatic networking to face current and future challenges.

\section{Acknowledgements}

SGOV thanks the Japanese Government (Monbukagakusho) Scholarship. Authors thank Science and Technology Research Partnership for Sustainable Development (SATREPS) and the University of Tsukuba that allowed the development of present research product.

\section{Conflicts of Interest}

The authors declare no conflicts of interest regarding the publication of this paper.

\section{References}

[1] Haussmann, B.I.G., Parzies, H.K., Presterl, T., Susic and Miedaner, T. (2004) Plant Genetic Resources in Crop Improvement. Plant Genetic Resources, 2, 3-21.

[2] Bermejo, J.E.H. and Leòn, J. (1994) Neglected Crops 1492 from a Different Perspective. FAO, Rome.

[3] Adhikari, L., Hussain, A. and Rasul, G. (2017) Tapping the Potential of Neglected and Underutilized Food Crops for Sustainable Nutrition Security in the Mountains of Pakistan and Nepal. Sustainability, 9, 291. https://doi.org/10.3390/su9020291

[4] FAO (2010) The Second Report of the State of the World's Plant Genetic Resources for Food and Agriculture. FAO, Rome.

[5] United Nations, General Assembly (2015) Resolution Adopted by the General Assembly on 25 September 2015. United Nations, Washington DC.

[6] Prescott-Allen R. and Prescott-Allen, C. (1990) How Many Plants Feed the World? 
Conservation Biology, 4, 365-374.

https://doi.org/10.1111/j.1523-1739.1990.tb00310.x

[7] FAO (1998) The State of the World's Plant Genetic Resources for Food and Agriculture. FAO, Rome.

[8] Füleky, G. (2016) Cultivated Plants Primarily as Food Sources. Encyclopedia of Life Support System, Vol. 1, UNESCO, Paris.

[9] Padulosi, S., Hodgkin, T., Williams, J.T. and Haq, N. (1999) Underutilized Crops: Trends, Challenges and Opportunities in the 21st Century. IPGRI, Rome.

[10] Nyadanu, D., Aboagye, L.M., Akromah, R. and Dansi, A. (2016) Agro-Biodiversity and Challenges of On-Farm Conservation: The Case of Plant Genetic Resources of Neglected and Underutilized Crop Species in Ghana. Genetic Resources and Crop Evolution, 63, 1397-1409. https://doi.org/10.1007/s10722-015-0327-2

[11] Thrupp, L.A. (2000) Linking Agricultural Biodiversity and Food Security: The Valuable Role of Agrobiodiversity for Sustainable Agriculture. Journal of International Affairs, 76, 265-281. https://doi.org/10.1111/1468-2346.00133

[12] van de Wouw, M., Kik, C., van, Hintum, T., van, Treuren, R. and Visser, B. (2009) Genetic Erosion in Crops: Concept, Research Results and Challenges. Plant Genetic Resources C, 8, 1-15. https://doi.org/10.1017/S1479262109990062

[13] Dansi, A., Vodouhè, R., Azokpota, P., Yedomonhan, H., Assogba, P., Adjantin, A., et al. (2012) Diversity of the Neglected and Underutilized Crop Species of Importance in Benin. The Scientific World Journal, 212, Article ID: 932947.

https://doi.org/10.1100/2012/932947

[14] Padulosi, S., Thompson, J. and Rudebjer, P. (2013) Fighting Poverty, Hunger and Malnutrition with Neglected and Underutilized Species (NUS): Needs, Challenges and the Way Forward. Bioversity International, Rome.

[15] Nonaka, S. and Ezura, H. (2016) Genetic Engineering of Important Breeding Traits in Solanaceae and Cucurbitacae. In: Functional Genomics and Biotechnology in Solanaceae and Cucurbitacae Crops, Springer International Publishing, Berlin, Heidelberg, 221-238. https://doi.org/10.1007/978-3-662-48535-4_13

[16] Jeffrey, C. (1980) A Review of the Cucurbitaceae. Botanical Journal of the Linnean Society, 81, 233-247. https://doi.org/10.1111/j.1095-8339.1980.tb01676.x

[17] Smith, B.D. (1997) The Initial Domestication of Cucurbita pepo in the Americas 10,000 Years Ago. Science, 276, 932-934. https://doi.org/10.1126/science.276.5314.932

[18] FAOSTAT Database. http://www.fao.org/faostat/en/\#data/QC

[19] Yong, X. and Guo, S. (2017) The Watermelon Genome. In: Genetics and Genomics of Cucurbitaceae, Springer International Publishing, Cham, 198-210. https://doi.org/10.1007/7397_2016_22

[20] Behera, T.K., Sureja, A.K., Islam, S., Munshi, A.D. and Sidhu, A.S. (2012) Minor Cucurbits. In: Genetics, Genomics and Breeding of Cucurbits, Science Publishers, British Isles Enfield, 17-60. https://doi.org/10.1201/b11436-3

[21] Kirkbride, J.H. (1993) Biosystematics Monograph of the Genus Cucumis (Cucurbitaceae) North Carolina. Parkway Publishers, Boone.

[22] Robinson, R.W. and Decker-Walters, D.S. (2006) Cucurbits. Cab International, Wallingford, 226.

[23] Rahman, M., Islam, R. and Hossain, M. (2013) Taxonomy of Cucurbitaceae: Taxonomic Investigation of Wild and Cultivated Cucurbits of Northern Parts of Bangladesh. LAP Lambert Academic Publishing. 
[24] Weng, Y. and Sun, Z. (2012) Major Cucurbit Crops. In: Genetics, Genomics and Breeding of Cucurbits, Science Publishers, British Isles Enfield, 1-16. https://doi.org/10.1201/b11436-2

[25] Cadena-Iñiguez, J., Ruíz-Posadas, L.M., Trejo-López, C., Sánchez-García, P. and García-Medina, J.F. (2001) Regulación del intercambio de gases y relaciones hídricas en chayote (Sechiumedule (Jacq.) Swartz). Revista Chapingo Serie Horticultura, 7, 21-35. https://doi.org/10.5154/r.rchsh.2000.11.079

[26] Lira-Saade, R. (1996) Chayote. Sechiumedule (Jacq.) Sw. Promoting the Conservation and Use of Underutilized and Neglected Crops. Institute of Plant Genetics and Crop Plant Research, Rome.

[27] Prajapati, R.P., Kalariya, M., Parmar, S.K. and Sheth, N.R. (2010) Phytochemical and Pharmacological Review of Lagenariasicereria. Journal of Ayurveda and Integrative Medicine, 1, 266-272. https://doi.org/10.4103/0975-9476.74431

[28] N'dri, A.N.A., Zoro, B.I.A., Kouamé, L.P., Dumet, D. and Vroh-Bi (2016) On the Dispersal of Bottle Gourd [Lagenaria siceraria (Mol.) Standl.] Out of Africa: A Contribution from the Analysis of Nuclear Ribosomal DNA Haplotypes, Divergent Paralogs and Variant of 5.8S Protein Sequences. Plant Molecular Biology Reporter, 34, 454-466. https://doi.org/10.1007/s11105-015-0936-0

[29] Gill, N.S., Arora, R. and Kumar, S.R. (2011) Evaluation of Antioxidant, Anti-Inflammatory and Analgesic Potential of the Luffa acutangula Roxb. Var. amara. Research Journal of Phytochemistry, 5, 201-208. https://doi.org/10.3923/rjphyto.2011.201.208

[30] Kumar, P., Shaunak, I., Thakur, A.K. and Srivastava, D.K. (2017) Health Promising Medicinal Molecules in Vegetable Crops. Journal of Genetics and Genomes, 1, 102-106.

[31] Shendge, P.N. and Belemkar, S. (2018) Therapeutic Potential of Luffa acutangula: A Review on Its Traditional Uses, Phytochemistry, Pharmacology \& Toxicological Aspects. Frontiers in Pharmacology, 9, 1177-1191. https://doi.org/10.3389/fphar.2018.01177

[32] Jia, S., Schen, M., Zhang, F. and Xie, J. (2017) Recent Advances in Momordica charantia: Functional Components and Biological Activities. International Journal of Molecular Sciences, 18, 2555-2580. https://doi.org/10.3390/ijms18122555

[33] Lee, S.H., Jeong, Y.S., Song, J., Hwang, K.A., Noh, G.M. and Hwang, G. (2017) Phenolic Acid, Carotenoid Composition, and Antioxidant Activity of Bitter Melon (Momordica charantia L.) at Different Maturation Stages. International Journal of Food Properties, 20, 3078-3087. https://doi.org/10.1080/10942912.2016.1237961

[34] Kumar, N., Singh, S., Manvi and Gupta, R. (2011) Trichosanthes dioica Roxb.: An Overview. Pharmacognosy Reviews, 6, 61-67.

https://doi.org/10.4103/0973-7847.95886

[35] De Boer, H.J. and Thulin, M. (2012) Synopsis of Trichosanthes (Cucurbitaceae) Based on Recent Molecular Phylogenetic Data. PhytoKeys, 12, 23-33. https://doi.org/10.3897/phytokeys.12.2952

[36] Liyanage, R., Nadeeshani, H., Jayathilake, C., Visvanathan, R. and Wimalasiri, S. (2016) Comparative Analysis of Nutritional and Bioactive Properties of Aerial Parts of Snake Gourd (Trichosanthes cucumerina Linn.). International Journal of Food Science, 2016, Article ID: 8501637. https://doi.org/10.1155/2016/8501637

[37] De Donato, M. and Cequea, H. (1994) A Cytogenetic Study of Six Cultivars of the Chayote, Sechium edule Sw. (Cucurbitaceae). Journal of Heredity, 85, 238-241. https://doi.org/10.1093/oxfordjournals.jhered.a111444 
[38] Singh, B.K., Pathak, K.A. and Ngachan, S.V. (2012) Exploring Underutilized Chow-Chow in Mizoram. Indian Journal of Horticulture, 57, 3-5.

[39] Singh, B.K., Ramakrishna, Y. and Verma, V.K. (2015) Chow-Chow (Sechium edule): Best Alternative to Shifting Cultivation in Mizoram. Indian Journal Hill Farming, 28, 158-161.

[40] Salazar-Aguilar, S., Ruíz-Posadas, L., Del, M., Cadena-Iñiguez, J., Soto-Hernández, M., Santiago-Osorio, E., Aguiñiga-Sánchez, I., et al. (2017) Sechium edule (Jacq.) Swartz a New Cultivar with Antiproliferative Potential in a Human Cervical Cancer HeLa Cell Line. Nutrients, 9, 798. https://doi.org/10.3390/nu9080798

[41] Vieira, E.F., Pinho, O., Ferreira, I.M. and Delerue-Matos, C. (2018) Chayote (Sechium edule): A Review of Nutritional Composition, Bioactivities and Potential Applications. Food Chemistry Journal, 275, 557-568. https://doi.org/10.1016/j.foodchem.2018.09.146

[42] Jeffrey, C. (1980) Further Notes on Cucurbitaceae: V: The Cucurbitaceae of the Indian Subcontinent. Kew Bulletin, 34, 789-809. https://doi.org/10.2307/4119071

[43] Kocyan, A., Zhang, L.B., Schaefer, H. and Renner, S.S. (2007) A Multi/Locus Chloroplast Phylogeny for the Cucurbitaceae and Its Implications for Character Evolution and Classification. Molecular Phylogenetics and Evolution, 44, 533-537. https://doi.org/10.1016/j.ympev.2006.12.022

[44] Renner, S.S. and Schaefer, H. (2016) Phylogeny and Evolution of the Cucurbitaceae, in Genetics and Genomics of Cucurbitaceae. Springer, New York, 1-11. https://doi.org/10.1007/7397_2016_14

[45] Kumar, S.R. (2016) Cucurbits: History, Nomenclature, Taxonomy, and Reproductive Growth. In: Handbook of Cucurbits. Growth, Cultural Practices, and Physiology, CRC Press Taylor and Francis Group, Boca Raton, 3-22.

https://doi.org/10.1201/b19233-3

[46] Volz, S.M. and Renner, S.S. (2009) Phylogeography of the Ancient Eurasian Medicinal Plant Genus Bryonia (Cucurbitaceae) Inferred from Nuclear and Chloroplast Sequences. Taxon, 58, 550-560. https://doi.org/10.1002/tax.582019

[47] Bhowmick, B.K. and Jha, S. (2015) Differential Heterochromatin Distribution, Flow Cytometric Genome Size and Meiotic Behavior of Chromosomes in Three Cucurbitaceae Species. Scientia Horticulturae, 193, 322-329. https://doi.org/10.1016/j.scienta.2015.07.006

[48] Tepnner, H. (2004) Notes on Lagenaria and Cucurbita (Cucurbitaceae)-Review and New Contributions. Phyton, 44, 245-308.

[49] Prakash, K., Pandey, A., Radhamani, J. and Bisht, I.S. (2013) Morphological Variability in Cultivated and Wild Species of Luffa (Cucurbitaceae) from India. Genetic Resources and Crop Evolution, 60, 2319-2329. https://doi.org/10.1007/s10722-013-9999-7

[50] Filipowicz, N., Schaefer, H. and Renner, S.S. (2014) Revisiting Luffa (Cucurbitaceae) 25 Years after C. Heiser: Species Boundaries and Application of Names Tested with Plastid and Nuclear DNA Sequences. Systematic Botany, 39, 202-215. https://doi.org/10.1600/036364414X678215

[51] John, J.K., Antony, V.T. and Roy, Y.C. (2007) On the Occurrence, Distribution and Taxonomy of Momordica subangulata Blume ssp. reginera (G. Don) de Wilde in India. Genetic Resources and Crop Evolution, 54, 1327-1332. https://doi.org/10.1007/s10722-006-9114-4

[52] Bharathi, L.K. and John, K.J. (2013) Momordica Genus in Asia: An Overview. 
Springer, Berlin. https://doi.org/10.1007/978-81-322-1032-0

[53] Bharathi, L.K., Munshi, A.D., Vinod, Chandrashekaran, S., Behera, T.K. and Das, A.B. (2011) Cytotaxonomical Analysis of Momordica L. (Cucurbitaceae) Species of Indian Occurrence. Journal of Genetics, 90, 21-30. https://doi.org/10.1007/s12041-011-0026-5

[54] Mercado, P. and Lira, R. (1994) Contribución al conocimiento de los números cromosómicos de los géneros Sechium P. BR. Y Sicana Naudin (Cucurbitaceae). Acta Botánica Mexicana, 27, 7-13. https://doi.org/10.21829/abm27.1994.706

[55] Cadena-Iñiguez, J., Arévalo-Galarza, L., Avendaño-Arrazate, C.H., Soto-Hernández, M., Ruiz-Posadas, L.M., Santiago-Osorio, E., et al. (2007) Production, Genetics, Postharvest Management and Pharmacological Characteristics of Sechium edule (Jacq.) Sw. Fresh Produce, 1, 41-53.

[56] Bisognin, D.A. (2002) Origin and Evolution of Cultivated Cucurbits. Ciencia Rural, 32, 715-723. https://doi.org/10.1590/S0103-84782002000400028

[57] Schaefer, H., Heibl, C. and Renner, S.S. (2009) Gourds Afloat: A Dated Phylogeny Reveals an Asian Origin of the Gourd Family (Cucurbitaceae) and Numerous Oversea Dispersal Events. Proceedings of the Royal Society B: Biological Sciences, 276, 843-851. https://doi.org/10.1098/rspb.2008.1447

[58] Welbaum, G.E. (2015) Vegetable Production and Practices. CABI Publishing, 136-175. https://doi.org/10.1079/9781780645346.0000

[59] Sebastian, P., Schaefer, H., Telford, I.R.H. and Renner, S.S. (2010) Cucumber ( $\mathrm{Cu}$ cumis sativus) and Melon (C. melo) Have Numerous Wild Relatives in Asia and Australia, and the Sister Species of Melon Is from Australia. Proceedings of the Natural Academy of Sciences, 107, 14269-14273. https://doi.org/10.1073/pnas.1005338107

[60] Zhang, L.B., Simmons, M.P., Kocyan, A. and Renner, S.S. (2006) Phylogeny of the Cucurbitales Based on DNA Sequences of Nine Loci from the Genomes: Implications for Morphological and Sexual System Evolution. Molecular Phylogenetics and Evolution, 39, 305-322. https://doi.org/10.1016/j.ympev.2005.10.002

[61] Rubatzky, V.E. and Yamaguchi, M. (1997) World Vegetable: Principles, Production, and Nutritive Values. Chapman and Hall, London. https://doi.org/10.1007/978-1-4615-6015-9

[62] Verma, V.K. and Behera, T.K. (2007) Heterosis Studied in Ash Gourd [Benincasahispida (Thunb) Cogn.] for Yield and Related Traits. Journal of Tropical Agriculture, 45, 51-54.

[63] Decker-Walters, D.S.M., Wilkins-Ellert, S.M., Chung and Staub, J.E. (2004) Discovery and Genetic Assessment of Wild Bottle Gourd [Lagenariasiceraria (Mol.) Standley; Cucurbitaceae] from Zimbabwe. Economy Botany, 58, 501-508. https://doi.org/10.1663/0013-0001(2004)058[0501:DAGAOW]2.0.CO;2

[64] Clarke, A.C., Burtenshaw, M.K., McLenachan, P.A., Erickson, D.L. and Penny, D. (2006) Reconstructing the Origins and Dispersal of the Polynesian Bottle Gourd (Lagenaria siceraria). Molecular Biology and Evolution, 23, 893-900. https://doi.org/10.1093/molbev/msj092

[65] Dane, F. and Liu, J. (2007) Diversity and Origin of Cultivated and Citron Type Watermelon (Citrullus lanatus). Genetic Resources and Crop Evolution, 54, 1255-1265. https://doi.org/10.1007/s10722-006-9107-3

[66] Gürcan, K., Say, A., Yetişir, H. and Denli, N. (2015) A Study of Genetic Diversity in Bottle Gourd [Lagenaria siceraria (Molina) Standl.] Population, and Implication for the Historical Origins on Bottle Gourds in Turkey. Genetic Resources and Crop 
Evolution, 62, 321-333. https://doi.org/10.1007/s10722-015-0224-8

[67] Whitaker, T.W. and Carter, G.F. (1954) Oceanic Drift of Gourds-Experimental Observations. American Journal of Botany, 41, 697-700. https://doi.org/10.1002/j.1537-2197.1954.tb14397.x

[68] Whitaker, T.W. and Davis, G.N. (1962) Cucurbits. Botany, Cultivation, and Utilization. Interscience Publishers Inc., New York.

[69] Esteras, C., Nuez, F. and Picó, B. (2012) Genetic Diversity Studies in Cucurbits Using Molecular Tools. In: Genetics, Genomics and Breeding of Cucurbits, Science Publishers, British Isles Enfield, 140-198. https://doi.org/10.1201/b11436-6

[70] Yamaguchi, M. (1983) World Vegetable 1s: Principles, Production, and Nutritive Values. Van Nostrand Reinhold Company.

[71] Marr, K.L., Xia, Y.M. and Bhattarai, N.K. (2004) Allozyme, Morphological and Nutritional Analysis Bearing on the Domestication of Momordica charantia L. (Cucurbitaceae). Economic Botany, 58, 435-455. https://doi.org/10.1663/0013-0001(2004)058[0435:AMANAB]2.0.CO;2

[72] Schaefer, H. and Renner, S.S. (2010) A Three-Genome Phylogeny of Momordica (Cucurbitaceae) Suggests Seven Returns from Dioecy to Monoecy and Recent Long-Distance Dispersal to Asia. Molecular Phylogenetics and Evolution, 54, 553-560. https://doi.org/10.1016/j.ympev.2009.08.006

[73] Walters, T.W. and Decker-Walters, D.S. (1988) Balsam-Pear (Momordica charantia, Cucurbitaceae). Economy Botany, 42, 286-292.

[74] Chakravarty, H.L. (1990) Cucurbits of India and Their Role in the Development of Vegetable Crops. In: Biology and Utilization of the Cucurbitaceae, Cornell University Press, New York, 325-334.

[75] Dey, S.S., Singh, A.K., Chandel, D. and Behera, T.K. (2006) Genetic Diversity of Bitter Gourd (Momordica charantia L.) Genotypes Revealed by RAPD Markers and Agronomic Traits. Scientia Horticulturae, 109, 21-28. https://doi.org/10.1016/j.scienta.2006.03.006

[76] Gaikwad, A.B., Behera, T.K., Singh, A.K., Chandel, D., Karihaloo, J.L. and Staub, J.E. (2008) Amplified Fragment Length Polymorphism Analysis Provides Strategies for Improvement of Bitter Gourd (Momordica charantia L.). Horticultural Science, 43, 127-133. https://doi.org/10.21273/HORTSCI.43.1.127

[77] Cooper, W.E. and de Boer, H.J. (2011) A Taxonomic Revision of Trichosanthes L. (Cucurbitaceae) in Australia, Including One New Species from the Northern Territory. Austrobaileya, 8, 364-386.

[78] de Wilde, W.J.J.O. and Duyfjes, B.E.E. (2012) Keys to and Checklist of Species of the Genus Trichosanthes L. (Cucurbitaceae) in Indochina. Andansonia, 34, 265-278. https://doi.org/10.5252/a2012n2a6

[79] Koundinya, A.V.V. and Pandit, M.K. (2016) Snake Gourd: Taxonomy, Botany, Cultural Practices, Harvesting, Major Diseases, and Pests. In: Handbook of Cucurbits. Growth, Cultural Practices, and Physiology, CRC Press Taylor and Francis Group, Boca Raton, 533-546. https://doi.org/10.1201/b19233-42

[80] Bhaduri, P.N. and Bose, P.C. (1947) Cyto-Genetical Investigations in Some Common Cucurbits, with Special Reference to Fragmentation of Chromosomes as a Physical Basis of Speciation. Journal of Genetics, 48, 237-256.

https://doi.org/10.1007/BF02989384

[81] Beevy, S.S. and Kuriachan, P. (1996) Chromosome Numbers of the Southern Indian Cucurbitaceae and a Note of the Cytological Evolution in the Family. Journal Cy- 
tology Genetics, 31, 65-71.

[82] Singh, A.K. (1979) Cucurbitaceae and Polyploidy. Cytologia, 44, 897-905. https://doi.org/10.1508/cytologia.44.897

[83] Ingle, J., Timmis, J.N. and Sinclair, J. (1975) The Relationship between Satellite Deoxyribonucleic Acid, Ribosomal Ribonucleic Acid Gene Redundancy, and Genome Size in Plants. Plant Physiology, 55, 496-501. https://doi.org/10.1104/pp.55.3.496

[84] Arumuganathan, K. and Earle, E.D. (1991) Nuclear DNA Content of Some Important Plant Species. Plant Molecular Biology Reporter, 9, 208-218. https://doi.org/10.1007/BF02672069

[85] Bennett, M.D. and Smith, J.B. (2012) Plant DNA C-Values Database. Kew Royal Botanical Garde. http://www.fao.org/faostat/en/\#data/QC

[86] Bennett, M.D., Smith, J.B. and Heslop-Harrison, J.S. (1982) Nuclear DNA Amounts in Angiosperms. Proceedings of the Royal Society B: Biological Sciences, 216, 179-199. https://doi.org/10.1098/rspb.1982.0069

[87] Bennet, M.D. and Smith, J.B. (1976) Nuclear DNA Amounts in Angiosperms. Philosophical Transaction of the Royal Society B, 274, 227-274. https://doi.org/10.1098/rstb.1976.0044

[88] Achigano-Dako, E.G., Fuchs, J., Ahanchede, A. and Blattner, F.R. (2008) Flow Cytometric Analysis in Lagenaria siceraria (Cucurbitaceae) Indicates Correlation of Genome Size with Usage Types and Growing Elevation. Plant Systematics and EvoIution, 276, 9-19. https://doi.org/10.1007/s00606-008-0075-2

[89] Chattopadhyay, D. and Sharma, A.K. (1991) Chromosome Studies and Nuclear DNA in Relation to Sex Difference and Plant Habit in Two Species of Cucurbitaceae. Cytologia, 56, 409-417. https://doi.org/10.1508/cytologia.56.409

[90] Thomas, C.A. (1971) The Genetic Organization of Chromosomes. Annual Review of Genetics, 5, 237-256. https://doi.org/10.1146/annurev.ge.05.120171.001321

[91] Ohri, D. (1998) Genome Size Variation and Plant Systematics. Annals of Botany, 82, 75-83. https://doi.org/10.1006/anbo.1998.0765

[92] Greilhuber, J. (1998) Intraspecific Variation in Genome Size: A Critical Reassessment. Annals of Botany, 82, 27-35. https://doi.org/10.1006/anbo.1998.0725

[93] Dolězel, J., Greilhuber, J. and Suda, J. (2007) Estimation of Nuclear DNA Content in Plants Using Flow Cytometry. Nature Protocols, 2, 2233-2244. https://doi.org/10.1038/nprot.2007.310

[94] Leitch, I.J. and Bennett, M.D. (2007) Genome Size and Its Uses: The Impact of Flow Cytometry. In: Flow Cytometry with Plant Cells. Analysis of Genes, Chromosomes and Genomes, John Wiley \& Sons, Weinheim, 153-176. https://doi.org/10.1002/9783527610921.ch7

[95] Greilhuber, J. and Leitch, I.J. (2013) Genome Size and the Phenotype. In: Plant Genome Diversity 2, Springer, New York, 323-344. https://doi.org/10.1007/978-3-7091-1160-4_20

[96] Mandàk, B., Krak, K., Vìt, P., Pavlikova, Z., Lomonosova, M.N., Habibi, F., et al. (2016) How Genome Size Variation Is Linked with Evolution within Chenopodium Sense Lato. Perspectives in Plant Ecology and Systematics, 23, 18-32. https://doi.org/10.1016/j.ppees.2016.09.004

[97] Nimmakayala, P., Saminathan, T., Abburi, V.L., Yadav, L.K., Tomason, Y., Levi, A., et al. (2017) Comparative Genomics of the Cucurbitaceae, in Genetics and Genomics of Cucurbitaceae. Springer International Publishing, Cham, 229-240. 
https://doi.org/10.1007/7397_2017_2

[98] Schaefer, H. and Renner, S.S. (2011) Phylogenetic Relationships in the Order Cucurbitales and a New Classification of the Gourd Family (Cucurbitaceae). Taxon, 60, 122-138. https://doi.org/10.1002/tax.601011

[99] Lira-Saade, R. and Nee, M. (1999) A New Species of Sechium sect. Frantzia (Cucurbitaceae, Sicyeae, Sicynae) from Mexico. Brittonia, 51, 204-209. https://doi.org/10.2307/2666628

[100] Cadena-Iñiguez, J., Avendaño-Arrazate, C.H., Soto-Hernández, M., Ruiz-Posadas, L.M., Aguirre-Medina, J.F. and Arévalo-Galarza, L. (2008) Intraspecific Variation of Sechium edule Jacq.) Sw. in the State of Veracruz, Mexico. Genetic Resources and Crop Evolution, 55, 835-847. https://doi.org/10.1007/s10722-007-9288-4

[101] Newstrom, L.E. (1990) Origin and Evolution of Chayote, Sechium edule. In: Biology and Utilization of the Cucurbitaceae, Cornell University Press, Ithaca, 141-149.

[102] Abdelnour, A. and Rocha, O.J. (2008) Genetic Characterization of a Collection of Chayote, Sechium edule (Jacq.) Swartz, in Costa Rica by Using Isozyme Markers. Genetic Resources and Crop Evolution, 55, 163-170.

https://doi.org/10.1007/s10722-007-9225-6

[103] Machida-Hirano, R., Cortès-Cruz, M., Amaro-Gonzàlez, B.A., Caden-Iñiguez, J., Shirata, K. and Watanabe, K.N. (2015) Isolation and Characterization of Novel Microsatellite Markers in Chayote [Sechium edule (Jacq.) Sw.]. American Journal of Plant Sciences, 6, 2033-2041. https://doi.org/10.4236/ajps.2015.613203

[104] Cadena-Iñiguez, J. and Arévalo-Galarza, L. (2011) Las variedades del chayote (Sechium edule (Jacq.) Sw.) y su comercio mundial. Colegio de Posgraduados, Mexico.

[105] Cadena-Iñiguez, J., Avendaño-Arrazate, C.H., Cisneros-Salgado, V.M., ArévaloGalarza, L., Ruiz-Posada, L.M., Aguirre-Medina, J., et al. (2017) Guía de descriptores varietales de Sechium edule (Jacq.) Sw. para protección legal de su variación. Colegio de Postgraduados, Mexico.

[106] Avendaño-Arrazate, C.H., Cadena-Iñiguez, J., Arévalo-Galarza, L., Campos-Rojas, E., Cisneros-Solano, V.M. and Aguirre-Medina, J.F. (2010) Las variedades de chayote mexicano, recurso ancestral con potencial de comercialización. Grupo Interdisciplinario de Investigación en Sechium eduleen Mexico, Mexico.

[107] Fielder, H., Smith, C., Ford-Lloyd, B. and Maxted, N. (2016) Enhancing the Conservation of Crop Wild Relatives in Scotland. Journal for Nature Conservation, 29, 51-61. https://doi.org/10.1016/j.jnc.2015.11.002

[108] Sonnino, A. (2017) International Instruments for Conservation and Sustainable Use of Plant Genetic Resources for Food and Agriculture: An Historical Appraisal. Diversity, 9, 2-19. https://doi.org/10.3390/d9040050

[109] Singh, A.K. (1990) Cytogenetics and Evolution in the Cucurbitaceae. In: Biology and Utilization of the Cucurbitaceae, Cornell University Press, Ithaca, 10-28.

[110] De Storme, N. and Mason, A. (2014) Plant Speciation through Chromosome Instability and Policy Change: Cellular Mechanisms, Molecular Factors and Evolutionary Relevance. Current Plant Biology, 1, 10-33. https://doi.org/10.1016/j.cpb.2014.09.002

[111] Roy, R.P., Saran, S. and Dutt, B. (1991) Cytogenetic of the Cucurbitaceae. In: Development in Plant Genetics and Breeding, Vol. 2, Elsevier, New York, 181-199. https://doi.org/10.1016/B978-0-444-88260-8.50015-X

[112] Pandey, S., Kumar, S., Mishra, U., Rai, A., Singh, M. and Rai, M. (2008) Genetic Diversity in Indian Ash Gourd (Benincasa hispida) Accessions as Revealed by 
Quantitative Traits and RAPD Markers. Scientia Horticulturae, 118, 80-86. https://doi.org/10.1016/j.scienta.2008.05.031

[113] Dhiman, K., Gupta, A., Sharma, D.K., Gill, N.S. and Goyal, A. (2012) A Review on the Medicinally Important Plants of the Family Cucurbitaceae. Asian Journal of Clinical Nutrition, 4, 16-26. https://doi.org/10.3923/ajcn.2012.16.26

[114] Kaushik, U., Aeri, V. and Mir, S.R. (2015) Cucurbitacins and Insight into Medical Leads from Nature. Pharmacognosy Review, 9, 12-18. https://doi.org/10.4103/0973-7847.156314

[115] Dubey, R.Kr., Singh, V., Upadhyay, G. and Ram, H.H. (2016) Snap Melon. In: Handbook of Cucurbits: Growth, Cultural Practices, and Physiology, CRC Press Taylor and Francis Group, Boca Raton, 489-498.

[116] Varghese, R.M. (1973) Cytology of Sechium edule Sw. Current Science, 42, 30.

[117] Kates, H.R., Soltis, P.S. and Soltis, D.E. (2017) Evolutionary and Domestication History of Cucurbita (Pumpkin and Squash) Species Inferred from 44 Nuclear Loci. Molecular Phylogenetics and Evolution, 111, 98-109. https://doi.org/10.1016/j.ympev.2017.03.002

[118] Ramachadran, C. and Narayan, R.K.J. (1985) Chromosomal DNA Variation in Cucumis. Theoretical and Applied Genetics, 69, 497-502. https://doi.org/10.1007/BF00251092

[119] Marie, D. and Brown, S.C. (1993) A Cytometric Exercise in Plant DNA Histograms, with 2C Values for 70 Species. Biology of the Cell, 78, 41-51. https://doi.org/10.1016/0248-4900(93)90113-S

[120] Tatum, T.C., Nunez, L., Kushad, M.M. and Rayburn, A.L. (2006) Genome Size Variation in Pumpkin (Cucurbita sp.). Annals of Applied Biology, 149, 145-151. https://doi.org/10.1111/j.1744-7348.2006.00079.x 